\title{
Taxonomic Study of Bacteroides oralis and Related Organisms and Proposal of Bacteroides veroralis sp. nov.
}

\author{
JUNKO WATABE, ${ }^{1 *}$ YOSHIMI BENNO, ${ }^{1}$ AND TOMOTARI MITSUOKA ${ }^{1,2}$ \\ The Institute of Physical and Chemical Research, Wako, Saitama, 351, ${ }^{1}$ and Department of Biomedical \\ Science, Faculty of Agriculture, University of Tokyo, Bunkyo-ku, Tokyo, 113, ${ }^{2}$ Japan
}

The genetic and phenotypic properties of 18 strains which were considered to be Bacteroides oralis or related organisms were examined. These strains were differentiated into several groups on the basis of deoxyribonucleic acid homology, physiological properties, guanine-plus-cytosine content of the deoxyribonucleic acid, and electrophoretic patterns of cell proteins. The groups were considered to constitute separate species. Strains of group I (strains VPI 7570A, WAL 3030, and 1221) belonged to the newly described species Bacteroides denticola. Strain VPI 8906D (group II) has been designated a new species, Bacteroides buccalis, by Shah and Collins. Strain VPI D27B-24 (group III) is the type strain of B. oralis. However, the biological properties of none of the three groups described above fit the original description of $B$. oralis (Loesche et al. 1964). Strain VPI D22A-7 ${ }^{\mathrm{T}}$ did not belong to any of the three groups but had phenotypic properties that matched the phenotypic properties given in the first description of $B$. oralis. We propose the name Bacteroides veroralis for this organism and have deposited strain VPI D22A-7 in the American Type Culture Collection (= ATCC 33779) as the type strain.

Bacteroides oralis was first described by Loesche et al. (16) as a gram-negative anaerobic bacillus from the oral cavity of humans. The biochemical characteristics of $B$. oralis reportedly are similar to those of Bacteroides melaninogenicus subsp. melaninogenicus and Bacteroides ruminicola $(6,16,25)$, except that $B$. melaninogenicus produces a black pigment $(7$, $15)$ and $B$. ruminicola requires hemin for growth and ferments pentose (1). The type strain of $B$. oralis designated by Loesche et al. (16) apparently has been lost, and the strain now designated 7CM has been reclassified as Bacteroides vulgatus (23). A second strain deposited by Loesche et al. as representative of $B$. oralis (strain Loesche 8B [= ATCC 15930]) was reclassified as $B$. melaninogenicus subsp. melaninogenicus (4) and is now the type strain of Bacteroides loescheii $(8)$. B. oralis VPI D27B-24 (= ATCC 33269) has been designated the type strain of $B$. oralis.

The present study was undertaken to clarify the relationships of strains which are similar to $B$. oralis $(5,23,27,29)$; this was done by examining the physiological and biochemical characteristics, deoxyribonucleic acid (DNA) base compositions, DNA homologies, and protein electrophoretic mobility patterns of these strains.

\section{MATERIALS AND METHODS}

Bacterial strains. We studied the following strains of $B$. oralis and similar organisms: VPI $7570 \mathrm{~A}$, from $\mathrm{T}$.
Hofstad; WAL 3030, from S. M. Finegold; 1221, from S. S. Socransky; WPH 179, from J. G. Collee; 5540 and 7880, from H. Werner; VPI 8906D, VPI D22A-7 ${ }^{\mathrm{T}}$, VPI E1S-8, VPI D25B-5, VPI 5832, VPI 9958, VPI D27B-24 $4^{\mathrm{T}}$ (= ATCC $33269^{\mathrm{T}}$ [type strain of $B$. oralis]), VPI $6822^{\mathrm{T}}$ (= ATCC $29303^{\mathrm{T}}$ [type strain of B. bivius]), and VPI 6318, from W. E. C. Moore; $\operatorname{HS4}^{\mathrm{T}}{ }^{\mathrm{T}}$ = NCDO $2354^{\mathrm{T}}$ [type strain of $B$. buccalis]), from J. M. Hardie; B56020 (B. ruminicola- $B$. oralis group III), from our collection; and ATCC $25845^{\mathrm{T}}$ (type strain of $B$. melaninogenicus subsp. melaninogenicus), from the American Type Culture Collection.

Maintenance of cultures. Strains were grown on modified Eggerth-Gagnon (EG) agar (19) and in peptone yeast extract Fildes solution glucose broth (13) at $37^{\circ} \mathrm{C}$ in anaerobic steelwool jars under an atmosphere containing $100 \% \mathrm{CO}_{2}$. All strains were maintained on prereduced EG agar liver slants with $\mathrm{H}_{2} \mathrm{CO}_{3}-\mathrm{CO}_{2}$ buffer (19) and stored at $4^{\circ} \mathrm{C}$. New transfers were made at monthly intervals.

Cultural and biochemical tests. The methods used in this study for cultural and biochemical characterization of the strains have been described previously (11). For fermentation tests, the $\mathrm{pH}$ after 7 days of incubation was measured with a glass electrode. $\mathrm{A} \mathrm{pH}$ decrease of 0.4 to $0.5 \mathrm{U}$ below the $\mathrm{pH}$ values of control cultures grown without fermentable carbohydrate was interpreted as weak fermentation, and greater decreases were considered positive. Fatty acid production was analyzed by the method of Holdeman et al. (6). Colonies on EG agar supplemented with 5\% laked rabbit or human blood were examined for pigmentation. Colonies were held for 7 days before recording absence of pigmentation.

Preparation of DNA. For the preparation of DNA, cells were grown in peptone yeast extract Fildes 
solution glucose broth. Cells were harvested in the late logarithmic phase of growth and washed twice with $0.15 \mathrm{M} \mathrm{NaCl}-0.1 \mathrm{M}$ ethylenediaminetetraacetic acid (pH 8.0). For the preparation of tritium-labeled DNA, the organisms were grown in prereduced EG broth containing [methyl $-{ }^{3} \mathrm{H}$ ]thymidine $(1 \mu \mathrm{Ci} / \mathrm{ml}$; Radiochemical Centre Ltd., Amersham, England). DNA was isolated by a modification of the procedures of Marmur $(17,22)$. DNA purity was assessed by the ratio of extinction at $230 \mathrm{~nm}$ to extinction at $260 \mathrm{~nm}$. The amount of DNA was estimated by measuring the hyperchromic shift during thermal denaturation (3).

DNA base composition. The guanine-plus-cytosine $(\mathrm{G}+\mathrm{C})$ contents of the DNA preparations were determined by the thermal melting point method (18), using an automatic recording spectrophotometer (Komatsu Electronics, Tokyo, Japan). Calf thymus DNA was included in each test as a standard.

DNA homology experiments. The methods used for immobilizing DNA on nitrocellulose filters and for DNA competition experiments were the procedures of Johnson and Cummins (11), with some modification. Native DNA $(50 \mu \mathrm{g} / \mathrm{ml})$ was denatured by boiling for $10 \mathrm{~min}$ in $0.1 \times \mathrm{SSC}(1 \times \mathrm{SSC}$ is $0.15 \mathrm{M} \mathrm{NaCl}$ plus $0.015 \mathrm{M}$ trisodium citrate, $\mathrm{pH} 7.0$ ), and the denatured DNA was immobilized on 4.9-mm nitrocellulose membrane filters (Toyo Roshi Ltd., Tokyo, Japan) by slow filtration. At the time of an experiment, small filters (3 by $9 \mathrm{~mm}$ ) were cut from a large filter, and each small filter contained 4 to $8 \mu \mathrm{g}$ of DNA. The labeled DNA and competitor DNA were sonicated twice $(30 \mathrm{~s}$ each time) in $0.1 \times \mathrm{SSC}$ and denatured by heating at $100^{\circ} \mathrm{C}$ for $10 \mathrm{~min}$. Then $10 \mu \mathrm{l}(3,000 \mathrm{cpm} / 10 \mu \mathrm{l})$ of labeled DNA fragments homologous to the DNA on the filter and $100 \mu$ l (containing $100 \mu \mathrm{g}$ of DNA) of competitor DNA in $2.2 \times \mathrm{SSC}$ were added to small incubation vials. The vials were incubated for $24 \mathrm{~h}$ at a temperature $25^{\circ} \mathrm{C}$ below the thermal melting point of the reference DNA in $1 \times \mathrm{SSC}$. The amount of DNA bound to the filter DNA was estimated by counting the radioactivity of the filter, using a liquid scintillation counter (Packard model 3330). DNA homology experiments were also performed by using the $\mathrm{S} 1$ nuclease procedure, as described by Johnson et al. (12). S1 nuclease digestion was conducted with $0.5 \mathrm{U}$ of $\mathrm{S} 1$ nuclease (Seikagaku Kogyo Co., Tokyo, Japan). After incubation for $15 \mathrm{~min}$ at $37^{\circ} \mathrm{C}$, an equal volume of $10 \%$ trichloroacetic acid was added to each tube. The tubes were cooled in a refrigerator at $4^{\circ} \mathrm{C}$ for at least $1 \mathrm{~h}$, and the precipitates were collected on nitrocellulose membrane filters (type HA; Millipore Corp., Bedford, Mass.). The membranes were dried, and the radioactivity was measured.

Preparation of cell-free extracts. Cells were grown anaerobically in peptone-yeast extract-Fildes solutionglucose broth for $24 \mathrm{~h}$ at $37^{\circ} \mathrm{C}$. Soluble enzyme extracts and acid-phenol-soluble proteins were prepared from the same batch of cells. Cells were harvested by
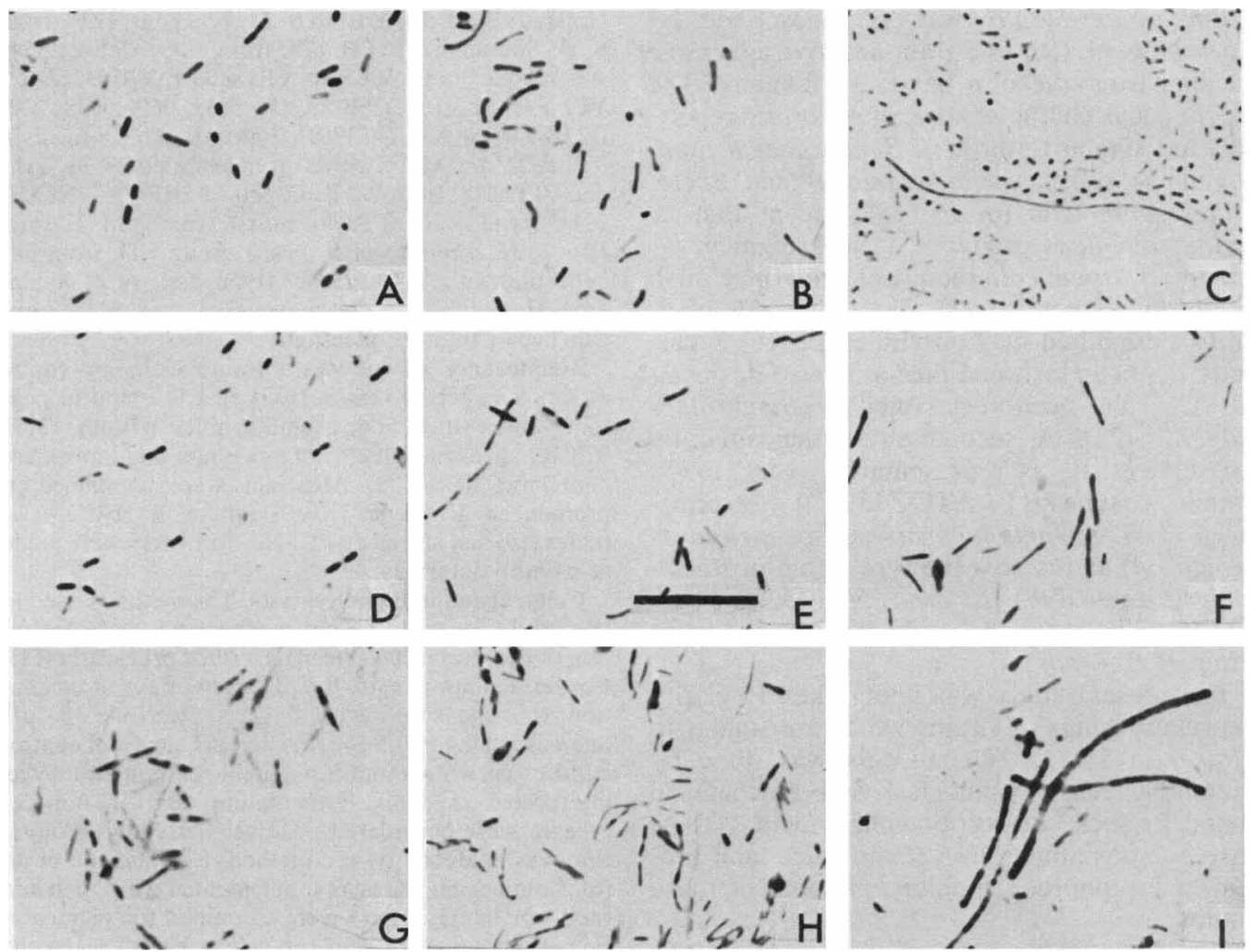

FIG. 1. Morphology of cells from 2-day-old surface colonies on EG agar. Bar $=10 \mu \mathrm{m}$. (A) $B$. denticola VPI 7570A. (B) B. buccalis VPI 8906D. (C) B. oralis VPI D27B-24 ${ }^{\mathrm{T}}$. (D) B. veroralis VPI D22A-7 ${ }^{\mathrm{T}}$. (E) B. bivius 7880. (F) Strain VPI E1S-8. (G) Strain VPI D25B-5. (H) Strain WPH 179. (I) Strain B56020. 
centrifugation at $8,000 \times g$ for $10 \mathrm{~min}$ and washed twice with $0.05 \mathrm{M}$ phosphate buffer ( $\mathrm{pH} 7.4$ ) containing $0.04 \%(\mathrm{vol} / \mathrm{vol}) 2$-mercaptoethanol. The cells were resuspended in the same buffer $(150 \mathrm{mg}$ [wet weight] per $\mathrm{ml}$ ) and were subjected to ultrasonic treatment for 1 to $3 \mathrm{~min}$ at $0^{\circ} \mathrm{C}$. After centrifugation at $20,000 \times g$ for $30 \mathrm{~min}$, the supernatants were used for electrophoretic enzyme assays; $1 \mathrm{ml}$ of fluid was mixed with $0.15 \mathrm{ml}$ of $0.1 \%$ bromophenol blue in $40 \%$ sucrose, and the preparation was stored at $-20^{\circ} \mathrm{C}$ until it was used.

The cell pellets were washed twice in $0.25 \mathrm{M} \mathrm{NaCl}$ and suspended in the same solution. The amount of protein was determined and adjusted to give $10 \mathrm{mg}$ of protein per $\mathrm{ml}$. The cell proteins then were extracted with phenol-acetic acid-water $(2: 1: 0.5, \mathrm{wt} / \mathrm{vol} / \mathrm{vol})$, as described by Rottem and Razin (21).

Polyacrylamide gel electrophoresis. Gels to detect enzymes were prepared by a modification of the method of Davis $(2,20)$. The separation gels contained $7.5 \%$ acrylamide, and the $\mathrm{pH}$ of the gels was adjusted to 8.9. Electrode buffer [6.0 $\mathrm{g}$ of tris(hydroxymethyl)aminomethane and $28.8 \mathrm{~g}$ of glycine in $1,000 \mathrm{ml}$ of water] was diluted 1:10 before use. The lower electrode served as the anode, and samples were electrophoresed at $15 \mathrm{~mA}$ for $30 \mathrm{~min}$. The current was then increased to $35 \mathrm{~mA}$ and held constant at this level until the bromophenol blue front reached the bottom of the gel. The gel was stained specifically to reveal malate dehydrogenase by using a solution containing $20 \mathrm{ml}$ of
0.1 M tris(hydroxymethyl)aminomethane hydrochlo-

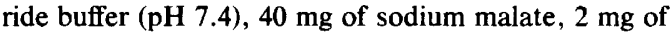
nicotinamide adenine dinucleotide, $4 \mathrm{mg}$ of Nitro Blue Tetrazolium, and $1 \mathrm{mg}$ of phenazine methosulfate.

Gels to separate phenol-acetic acid-soluble proteins were prepared by the methods of Rottem and Razin (21) and Zola et al. (30). These gels contained 7.5\% acrylamide, $35 \%$ acetic acid, and $5 \mathrm{M}$ urea; $10 \%$ acetic acid was used as the electrode buffer, and the lower electrode served as the cathode. Electrophoresis was carried out at a constant current of $15 \mathrm{~mA}$. The gels were stained with $0.05 \%$ Coomassie blue in $9 \%$ acetic acid-40\% methanol.

\section{RESULTS}

Cultural characteristics. The colonial and cellular appearances of the strains studied are shown in Fig. 1 and 2. All strains were gramnegative rod-shaped organisms. Gram stains of pure cultures showed predominantly short or long rod-shaped cells in pairs or, occasionally, short chains. After incubation for 2 days on EG agar, colonies of most strains were circular, entire, convex, translucent, smooth, and shiny. Strain VPI D25B-5 formed eroded semiopaque colonies. Strains VPI 7570A, WAL 3030, VPI
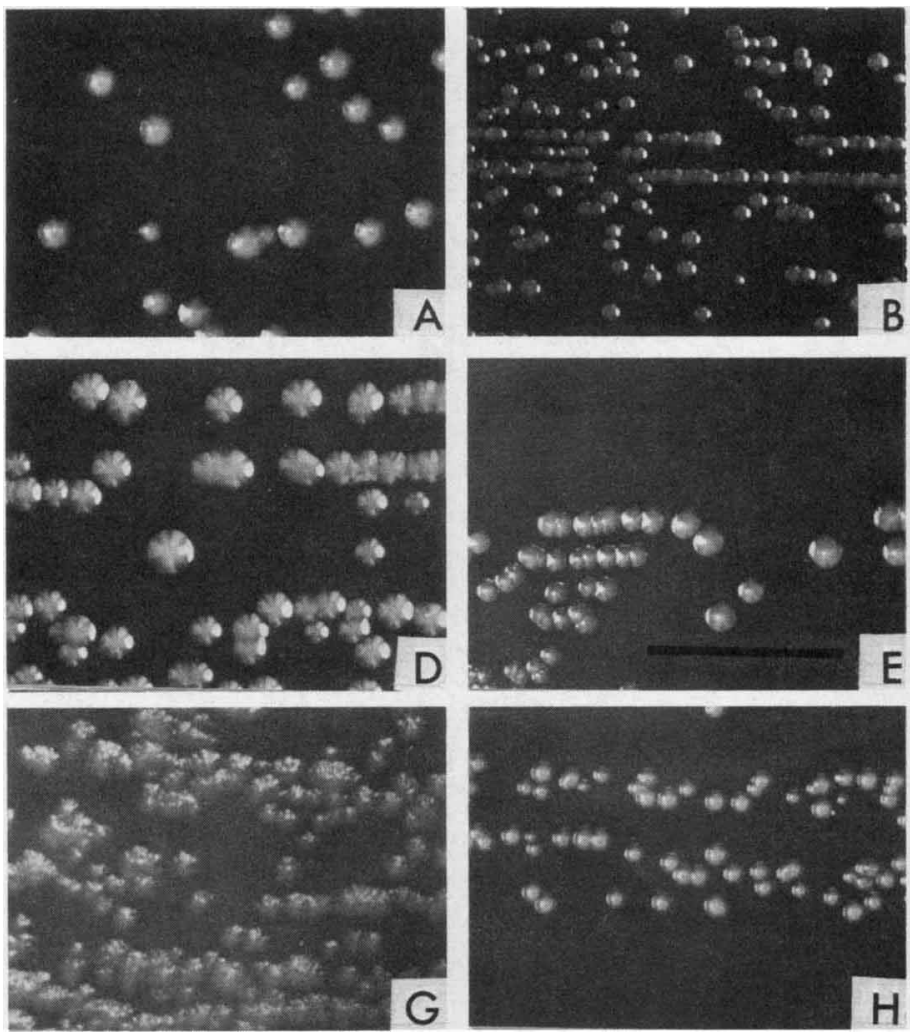
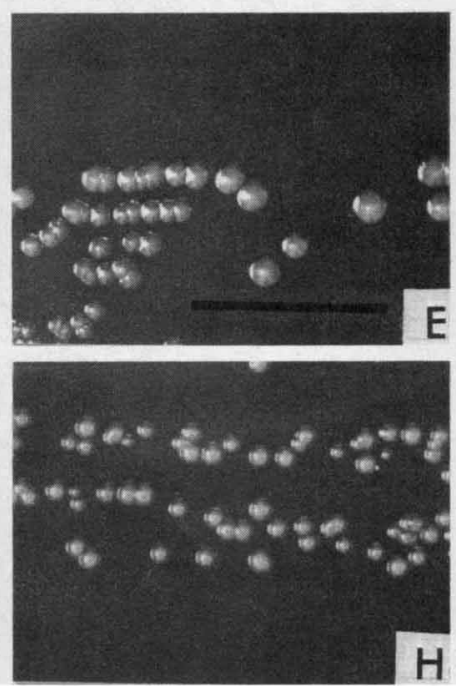
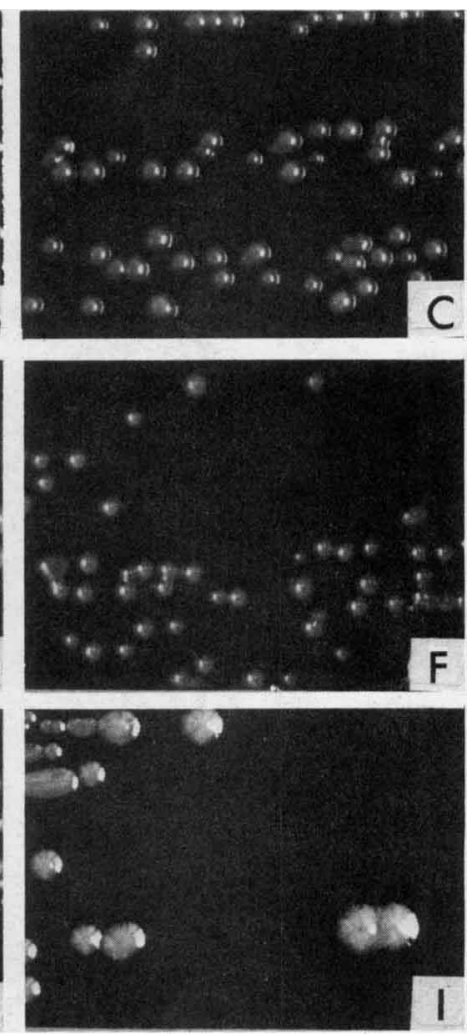

FIG. 2. Two-day-old surface colonies of Bacteroides strains on EG agar. Bar $=5 \mathrm{~mm}$. (A) B. denticola VPI 7570A. (B) B. buccalis VPI 8906D. (C) B. oralis VPI D27B-24 ${ }^{\mathrm{T}}$. (D) B. veroralis VPI D22A- $7^{\mathrm{T}}$. (E) B. bivius 7880 . (F) Strain VPI E1S-8. (G) Strain VPI D25B-5. (H) Strain WPH 179. (I) Strain B56020. 


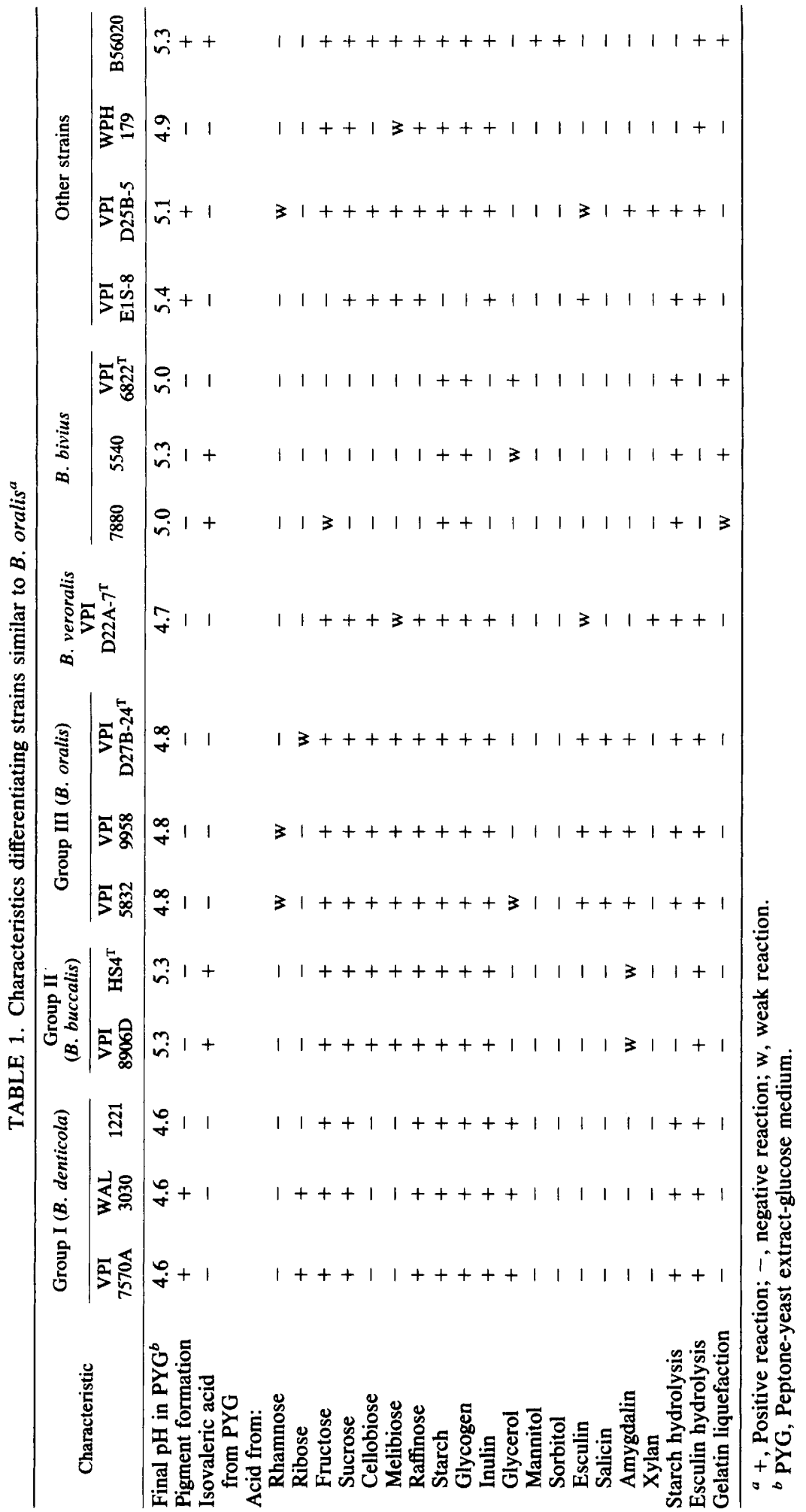


E1S-8, VPI D25B-5, and B56020 formed brown or black pigments on laked blood agar.

Biochemical reactions. The biochemical properties of the strains studied are shown in Table 1. In addition, all strains produced acetic acid and succinic acid on peptone yeast extract glucose medium and produced acid from glucose, mannose, galactose, maltose, and lactose. No strain produced acid from arabinose, xylose, trehalose, melezitose, adonitol, dulcitol, inositol, erythrytol, or gum arabic, produced gas, indole, or $\mathrm{H}_{2} \mathrm{~S}$, reduced nitrate, or grew in $20 \%$ bile.

G+C contents and DNA homologies. Table 2 shows the $\mathrm{G}+\mathrm{C}$ contents and DNA homologies among strains, as determined by the membrane competition method. Although DNA preparations of group II and III strains had similar $\mathbf{G}+\mathbf{C}$ contents ( 42.8 to $45.4 \mathrm{~mol} \%$ ), only low levels of DNA homology were found between these two groups. Strains VPI E1S-8 and VPI D25B-5 displayed levels of relatedness to each other of 70 and $68 \%$, indicating that these two strains may be members of the same species. Approximately $60 \%$ homology was obtained with strain VPI E1S-8 and competitor DNAs from strains VPI 5832, VPI 9958, and VPI D27B-24 ${ }^{\mathrm{T}}$ but not with the related strain VPI D25B-5. Thus, the relationships of these strains are not clear. The DNAs from strains WPH 179, B56020, and VPI D22A-7 $7^{\mathrm{T}}$ showed low relatedness to each other and the other bacteroides strains used.

Table 3 shows the DNA homologies among some of the strains as determined by the S1 nuclease method. With this method, strains VPI E1S-8 and VPI D25B-5 showed only 17.2 and $18 \%$ homology to each other and little or no relatedness to other strains.
Electrophoretic analysis. The range of the electrophoretic mobilities of malate dehydrogenase in the strains examined is shown in Fig. 3. The mobilities of the malate dehydrogenases obtained from the strains within each group were similar to each other. Strains VPI E1S-8 and VPI D25B-5 had similar protein bands, and strains VPI D22A-7 ${ }^{\mathrm{T}}$ and B56020 also were similar. The malate dehydrogenase of each of the other strains was distinct.

The electrophoretic patterns of the phenolacetic acid-soluble proteins of the strains are shown in Fig. 4. The patterns within each group (groups I, II, and III) were identical, and each was different from any other bacteroides species examined. The strains not in group I, II, or III had different protein electrophoretic patterns.

\section{DISCUSSION}

On the basis of phenotypic and genotypic characteristics, the strains which were similar to $B$. oralis were differentiated into three major groups and five unrelated strains. Because all of these organisms are obligately anaerobic, nonmotile, gram-negative rod-shaped bacteria that produce succinic acid and acetic acid, they belong to the genus Bacteroides (6). As van Steenbergen et al. (28) have shown, our results also indicate that strains similar to $B$. oralis are very heterogenous and fall into several different groups on the basis of $\mathrm{G}+\mathrm{C}$ content and DNA homology. The levels of DNA homology observed among strains of $B$. denticola, $B$. buccalis, and $B$. oralis are consistent with distinct species (10). Phenotypic characteristics and the electrophoretic protein patterns of the strains also differentiate these species.

TABLE 2. DNA homologies among strains of $B$. oralis and similar species

\begin{tabular}{|c|c|c|c|c|c|c|c|c|c|c|c|}
\hline \multirow{2}{*}{$\begin{array}{l}\text { Unlabeled } \\
\text { DNA from } \\
\text { strain: }\end{array}$} & \multirow{2}{*}{$\begin{array}{l}\text { Homology group } \\
\text { and/or species }\end{array}$} & \multicolumn{9}{|c|}{ \% Homology with reference DNA from strain: } & \multirow{2}{*}{$\underset{(\mathrm{mol} \%)}{\mathrm{G}+\mathrm{C} \text { content }}$} \\
\hline & & $\begin{array}{c}\text { VPI } \\
7570 \mathrm{~A}\end{array}$ & \begin{tabular}{|l} 
VPI \\
$8906 \mathrm{D}$
\end{tabular} & $\begin{array}{l}\text { VPI } \\
5832\end{array}$ & $\begin{array}{c}\text { VPI } \\
\text { D22A-7 }\end{array}$ & $\begin{array}{l}\text { VPI } \\
6822^{\mathrm{T}}\end{array}$ & $\begin{array}{c}\text { VPI } \\
\text { E1S-8 }\end{array}$ & $\begin{array}{c}\text { VPI } \\
\text { D25B-5 }\end{array}$ & $\begin{array}{c}\text { WPH } \\
179\end{array}$ & B56020 & \\
\hline VPI $7570 \mathrm{~A}$ & I (B. denticola) & 100 & 27 & 10 & 25 & 10 & 41 & 46 & 19 & 21 & 50.6 \\
\hline WAL 3030 & I (B. denticola) & 102 & 20 & 14 & 10 & 10 & 43 & 31 & 21 & 26 & 51.4 \\
\hline 1221 & I (B. denticola) & 89 & 38 & 35 & 32 & 11 & 44 & 33 & 28 & 20 & 50.1 \\
\hline VPI $8906 \mathrm{D}$ & II (B. buccalis) & 11 & 100 & 38 & 14 & 18 & 28 & 24 & 29 & 21 & 45.3 \\
\hline $\mathrm{HS}^{\mathrm{T}}$ & II (B. buccalis) & 15 & 96 & 26 & 14 & 20 & 29 & 42 & 32 & 24 & 45.4 \\
\hline VPI 5832 & III (B. oralis) & 12 & 32 & 100 & 40 & 10 & 61 & 34 & 24 & 15 & 43.1 \\
\hline VPI 9958 & III (B. oralis) & 20 & 38 & 107 & 42 & 36 & 61 & 36 & 27 & 26 & 42.8 \\
\hline VPI D27B-24 & III $(\boldsymbol{B}$. oralis $)$ & 29 & 16 & 90 & 30 & $\mathrm{ND}^{a}$ & 62 & 53 & 21 & 21 & 43.1 \\
\hline VPI D22A-7 & $B$. veroralis & 40 & 35 & 33 & 100 & ND & 42 & 42 & 21 & 21 & 42.1 \\
\hline 7880 & B. bivius & 24 & 36 & 36 & 29 & 88 & 35 & 29 & 21 & 24 & 37.5 \\
\hline 5540 & B. bivius & 32 & 24 & 25 & 29 & 84 & 26 & 24 & 18 & 32 & 37.5 \\
\hline VPI $6822^{\mathrm{T}}$ & B. bivius & 31 & 36 & 14 & 24 & 100 & 28 & 31 & 23 & 21 & 40.0 \\
\hline VPI 6318 & B. bivius & 24 & 36 & 34 & 31 & 98 & 31 & 33 & 17 & 18 & 40.0 \\
\hline VPI E1S-8 & Other & 20 & 42 & 42 & 17 & ND & 100 & 70 & 30 & 29 & 43.9 \\
\hline VPI D25B-5 & Other & 32 & 29 & 32 & 28 & ND & 68 & 100 & 18 & 32 & 46.4 \\
\hline WPH 179 & Other & 25 & 31 & 20 & 31 & 21 & 41 & 41 & 100 & 15 & 45.1 \\
\hline B56020 & Other & 18 & 44 & 23 & 11 & 10 & 32 & 32 & 29 & 100 & 50.0 \\
\hline
\end{tabular}

${ }^{a}$ ND, Not done. 
TABLE 3. DNA homologies among strains as determined by the $\mathrm{S} 1$ nuclease method

\begin{tabular}{lccc}
\hline \multirow{2}{*}{$\begin{array}{c}\text { Unlabeled DNA from } \\
\text { strain: }\end{array}$} & \multicolumn{3}{c}{$\begin{array}{c}\text { Homology with reference } \\
\text { DNA from strain: }\end{array}$} \\
\cline { 2 - 4 } & VPI & VPI & VPI \\
D22A-7 & D25B-5 & E1S-8 \\
\hline B. oralis group & & & \\
VPI D22A-7 & 100 & 4.7 & 7.1 \\
VPI D25B-5 & 0 & 100 & 17.2 \\
VPI E1S-8 & 11.8 & 18 & 100 \\
VPI D27B-24 & 9.1 & 2.7 & 5.5 \\
VPI 5832 & 0 & 5.5 & 6.3 \\
VPI 7570A & 0 & 0 & 0 \\
WPH 179 & 0 & 0 & 0 \\
B56020 & 2.5 & 0.4 & 0 \\
B. melaninogenicus & 9.9 & 0.7 & 0 \\
subsp. melanino- & & & \\
genicus ATCC & & & \\
25845 $^{\mathrm{T}}$ & & & \\
\hline
\end{tabular}

Strain VPI D27B-24 was listed as the type strain of $B$. oralis on the Approved Lists of Bacterial Names (26); this strain was identical to strains VPI 5832 and VPI 9958 (group III) phenotypically and genetically. Strains of this group fermented salicin, whereas according to the original description of the species $(16), B$. oralis should not ferment salicin.

van Steenbergen et al. (28) reported that strains VPI $8906 \mathrm{D}$ and $\mathrm{HS}^{\mathrm{T}}$ fit the original phenotypic description of $B$. oralis. However, strain VPI 8906D was isolated from umbilicus drainage, and strain $\mathrm{HS}^{\mathrm{T}}$ was isolated from a monkey mouth. Surface colonies of these two strains on blood agar were less $0.5 \mathrm{~mm}$ in diameter, whereas $B$. oralis was derived from a healthy human oral cavity and the colonies of $B$. oralis were reported to be 1 to $2 \mathrm{~mm}$ in diameter. We believe that strains VPI $8906 \mathrm{D}$ and $\mathrm{HS}^{\mathrm{T}}$ differ from the first description of $B$. oralis. Recently, Shah and Collins (24) described these strains as a new species, Bacteroides buccalis.

Of the strains examined, only strain VPI D22A-7 ${ }^{\mathrm{T}}$ possessed physiological, biochemical, and ecological characteristics which completely fit the original description of $B$. oralis. However, inasmuch as strain VPI D27B-24 was designated the type strain of $B$. oralis on the Approved Lists of Bacterial Names, this strain is a priori the type strain of $B$. oralis (14). Therefore, we propose the name Bacteroides veroralis sp. nov. for the strains that accurately fit the original description of $B$. oralis and designate strain VPI D22A-7 the type strain. A description of this species is given below.

Description of Bacteroides veroralis. Bacteroides veroralis $\mathrm{sp}$. nov. (ver'o.ral.is. L. adj. verus true; $\mathrm{L}$. adj. oralis pertaining to the mouth; N.L. masc. adj. veroralis the true oralis).

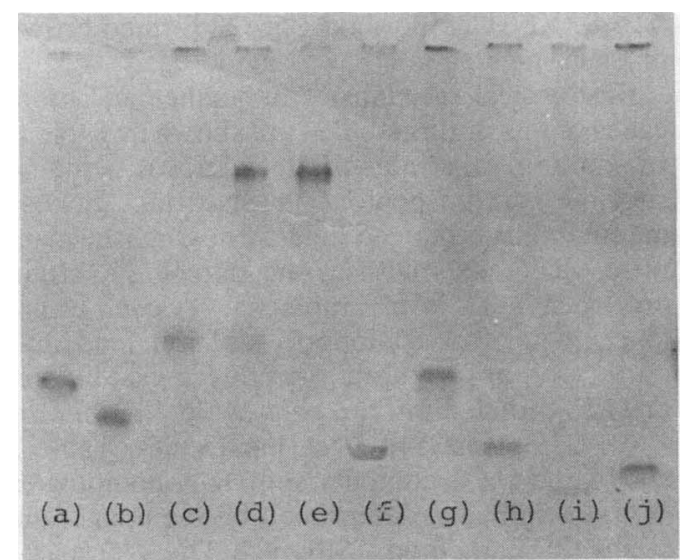

FIG. 3. Polyacrylamide gel stained for Bacteroides malate dehydrogenases. Lane a, B. denticola VPI 7570A; lane b, B. buccalis VPI 8906D; lane c, B. oralis VPI 5832; lane d, strain VPI E1S-8; lane e, strain VPI D25B-5; lane $\mathrm{f}, B$. veroralis VPI D22A-7 $7^{\mathrm{T}}$; lane $\mathrm{g}$, strain WPH 179; lane h, strain B56020; lane i, strain 7880; lane $\mathrm{j}, \boldsymbol{B}$. melaninogenicus subsp. melaninogenicus ATCC $25845^{\mathrm{T}}$.

Cell characteristics. Obligately anaerobic, nonmotile, nonsporeforming, gram-negative, rod-shaped cells $0.5 \mu \mathrm{m}$ wide by 1.0 to $1.5 \mu \mathrm{m}$ long. Gram strains of pure cultures show predominantly short rod-shaped cells in pairs or short chains of long rod-shaped cells (Fig. 1D).

Colonies. After incubation for 2 days on EG agar, colonies were 1.0 to $2.0 \mathrm{~mm}$ in diameter, circular, entire, convex, translucent, smooth, and shiny (Fig. 2D).

Cultural characteristics. Cultures in prereduced peptone yeast extract broth were moderately turbid, sometimes with a slight, smooth sediment. Growth was enhanced in broth supplemented with a fermentable carbohydrate. The optimal temperature for growth was about $37^{\circ} \mathrm{C}$. After good growth was observed in peptone-yeast extract-glucose medium cultures, the $\mathrm{pH}$ was 4.7. The $\mathrm{pH}$ of cultures in broth media without fermentable carbohydrate was usually 6.1.

Biochemical characteristics. Some biochemical reactions of this species are shown in Table 1 . Nitrate was not reduced. Neither indole nor hydrogen sulfide was produced. Bile did not stimulate growth. Little or no gas was formed from glucose. Acid and clots were produced in milk. Lecithinase was not produced in egg yolk agar.

Source. This organism was isolated from a human oral cavity.

$\mathbf{G}+\mathbf{C}$ content. The $\mathrm{G}+\mathrm{C}$ content of the DNA was $42.1 \mathrm{~mol} \%$.

Type strain. The type strain is VPI D22A- $7^{\mathrm{T}}$ $\left(=\right.$ ATCC $\left.33779^{\mathrm{T}}\right)$. 


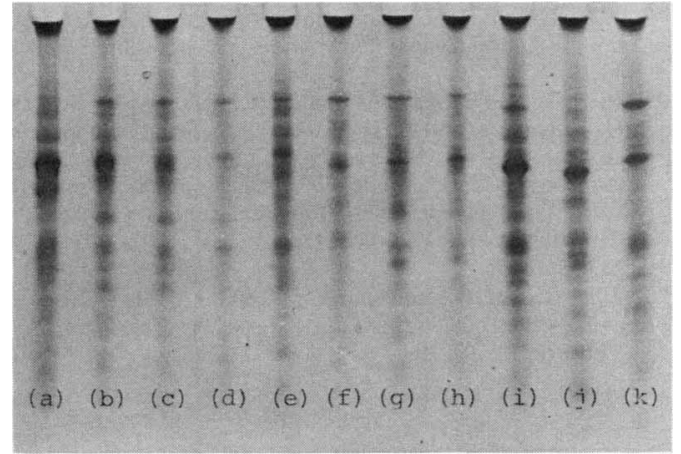

FIG. 4. Electrophoretic analysis of phenol-acetic acid-soluble proteins of Bacteroides strains. Lane a, $B$. denticola VPI 7570A; lane b, $B$. oralis VPI 5832; lane c, $B$. oralis VPI D27B- $24^{\mathrm{T}}$; lane d, strain VPI E1S8; lane e, strain VPI D25B-5; lane f, strain B56020; lane g, B. buccalis VPI $8906 \mathrm{D}$; lane h, B. buccalis $\mathrm{HS}^{\mathrm{T}}{ }^{\mathrm{T}}$; lane $\mathrm{i}, B$. veroralis VPI D22A- $7^{\mathrm{T}}$; lane $\mathrm{j}$, strain WPH 179; lane k, B. bivius 7880 .

Characteristics which differentiate $B$. veroralis from related organisms. $B$. veroralis is rather similar to the other organisms which we studied in colony size and biochemical characteristics. Table 1 shows the biochemical characteristics which are most useful for distinguishing $B$. veroralis from some members of the genus Bacteroides that are similar. $B$. veroralis produces acid from inulin, cellobiose, melibiose (weak), esculin (weak), and xylan, but not from glycerol and salicin; this species also hydrolyzes starch, but does not liquefy gelatin.

\section{ACKNOWLEDGMENTS}

We express our gratitude to W. E. C. Moore (Virginia Polytechnic Institute and State University), T. Hofstad (The Gade Institute, University of Bergen School of Medicine and Dentistry), S. M. Finegold (Wadsworth Veterans Administration Hospital), S. S. Socransky (Forsyth Dental Center, Harvard University School of Dental Medicine), J. G. Collee (Department of Bacteriology, University of Edinburgh Medical School), H. Werner (Institut für Medizinische Mikrobiologie und Immunologie), and J. M. Hardie (London Hospital Medical College Dental School) for supplying the strains used in this study.

\section{LITERATURE CITED}

1. Bryant, M. P., N. Small, C. Bouma, and H. Chu. 1958. Bacteroides ruminicola $\mathrm{n}$. sp. and Succinimonas amylolytica the new genus and species. Species of succinic acidproducing anaerobic bacteria of the bovine rumen. J. Bacteriol. 76:15-23.

2. Davis, B. J. 1964. Disc electrophoresis. II. Method and application to human serum proteins. Ann. N.Y. Acad. Sci. 121:404-427.

3. Doty, J., J. Marmur, J. Eigner, and C. Schildkraut. 1960. Strand separation and specific recombination in deoxyribonucleic acids: physical chemical studies. Proc. Natl. Acad. Sci. U.S.A. 46:461-476.

4. Holbrook, W. P., and B. I. Duerden. 1974. A comparison of some characteristics of reference strains of Bacteroides oralis with Bacteroides melaninogenicus. Arch. Oral Biol. 19:1231-1235.
5. Holbrook, W. P., B. I. Duerden, and A. G. Deacon. 1977 The classification of Bacteroides melaninogenicus and related species. J. Appl. Bacteriol. 43:259-273.

6. Holdeman, L. V., E. P. Cato, and W. E. C. Moore (ed.) 1977. Anaerobe laboratory manual, 4th ed. Anaerobe Laboratory, Virginia Polytechnic Institute and State University, Blacksburg.

7. Holdeman, L. V., and J. L. Johnson. 1977. Bacteroides disiens sp. nov. and Bacteroides bivius sp. nov. from clinical infections. Int. J. Syst. Bacteriol. 27:337-345.

8. Holdeman, L. V., and J. L. Johnson. 1982. Description of Bacteroides loescheii sp. nov. An emendation of the description of Bacteroides melaninogenicus (Oliver and Wherry) Roy and Kelly 1939 and Bacteroides denticolo Shah and Collins 1981. Int. J. Syst. Bacteriol. 32:399-409.

9. International Committee on Systematic Bacteriology. 1982. Validation of the publication of new names and new combinations previously effectively published outside the IJSB. List no. 8. Int. J. Syst. Bacteriol. 32:266-268.

10. Johnson, J. L. 1973. Use of nucleic-acid homologies in the taxonomy of anaerobic bacteria. Int. J. Syst. Bacteriol. 23:308-315.

11. Johnson, J. L., and C. S. Cummins. 1972. Cell wall composition and deoxyribonucleic acid similarities among the anaerobic coryneforms, classical propionibacteria, and strains of Arachnia propionica. J. Bacteriol. 109:10471066.

12. Johnson, J. L., C. F. Phelps, C. S. Cummins, J. London, and F. Gasser. 1980. Taxonomy of the Lactobacillus acidophilus group. Int. J. Syst. Bacteriol. 30:53-68.

13. Kaneuchi, C., K. Watanabe, A. Terada, Y. Benno, and T. Mitsuoka. 1976. Taxonomic study of Bacteroides clostridiiformis subsp. clostridiiformis (Burri and Ankersmit) Holdeman and Moore and of related organisms: proposal of Clostridium clostridiiforme (Burri and Ankersmit) comb. nov. and Clostridium symbiosum (Stevens) comb. nov. Int. J. Syst. Bacteriol. 26:195-204.

14. Lapage, S. P., P. H. A. Sneath, E. F. Lessel, V. B. D. Skerman, H. P. R. Seeliger, and W. A. Clark (ed.). 1975. International code of nomenclature of bacteria. 1975 Revision. American Society for Microbiology, Washington, D.C.

15. Loesche, W. J., and R. J. Gibbons. 1965. A practical scheme for identification of the most numerous oral gram negative anaerobic rods. Arch. Oral Biol. 10:723-725.

16. Loesshe, W. J., S. S. Socransky, and R. J. Gibbons. 1964. Bacteroides oralis, proposed new species isolated from the oral cavity of man. J. Bacteriol. 88:1329-1337.

17. Marmur, J. 1961. A procedure for the isolation of deoxyribonucleic acid from micro-organisms. J. Mol. Biol. 3:208-218.

18. Marmur, J., and P. Doty. 1962. Determination of the base composition of deoxyribonucleic acid from its thermal denaturation temperature. J. Mol. Biol. 5:109-118.

19. Mitsuoka, T., T. Sega, and S. Yamamoto. 1965. Eine verbesserte Methodik der qualitativen und quantitativen Analyse der Darmflora von Menshen und Tieren. Zentralbl. Bakteriol. Parasitenkd. Infektionskr. Hyg. Abt. 1 Orig. Reihe A 195:445-469.

20. Reid, M. S., and R. L. Bieleski. 1968. A simple apparatus for vertical flat-sheet polyacrylamide gel electrophoresis. Anal. Biochem. 22:374-381.

21. Rottem, S., and S. Razin. 1967. Electrophoretic patterns of membrane proteins of Mycoplasma. J. Bacteriol. 94:350-364.

22. Saito, H., and K. Miura. 1963. Preparation of transforming deoxyribonucleic acid by phenol treatment. Biochim. Biophys. Acta 72:642-644.

23. Shah, H. N., and M. D. Collins. 1980. Fatty acid and isoprenoid quinone composition in the classification of Bacteroides melaninogenicus and related taxa. J. Appl. Bacteriol. 48:75-87.

24. Shah, H. N., and M. D. Collins. 1981. Bacteroides buccalis, sp. nov., Bacteroides denticola, sp. nov., and Bacteroides pentosaceus, sp. nov., new species of the genus 
Bacteroides from the oral cavity. Zentralbl. Bakteriol. Parasitenkd. Infektionskr. Hyg. Abt. 1 Orig. Reihe C 2:235-241

25. Sharp, M. E. 1971. Serology of rumen bacteroides. J. Gen. Microbiol. 76:273-288.

26. Skerman, V. B. D., V. McGowan, and P. H. A. Sneath (ed.). 1980. Approved lists of bacterial names. Int. J. Syst. Bacteriol. 30:225-240.

27. Terada, A., K. Uchida, and T. Mitsuoka. 1976. Die Bacteroidaceenflora in den Faeces von Schweinen. Zentralbl. Bakteriol. Parasitenkd. Infektionskr. Hyg. Abt. 1 Orig. Reihe A 234:362-370.

28. van Steenbergen, T. J. M., H. N. Shah, J. M. Hardie, and
J. D. Graaff. 1980. Taxonomic studies on Bacteroides oralis. Antonie van Leeuwenhoek. J. Microbiol. Serol. 46:231.

29. Werner, H., H. Kunstek-Santos, C. Lohner, W. Schöps, H. J. Schmitz, and H. H. Karbe. 1977. Propionatnegative saccharolytische Bacteroides-Stämme (B. oralis)-Vorkommen, Identifizierung, Chemotherapeutika-Empfindlichkeit und serologisches Verhalten. Zentralbl. Bakteriol. Parasitenkd. Infektionskr. Hyg. Abt. 1 Orig. Reihe A 237:536-547.

30. Zola, H., W. Baxendale, and L. J. Sayer. 1970. Polyacrylamide gel electrophoresis of lysates of mycoplasmas. Res. Vet. Sci. 11:397-399. 